\title{
DINAMIKA PERUBAHAN PENGGUNAAN LAHAN DAN PREDIKSINYA UNTUK TAHUN 2025 SERTA KETERKAITANNYA DENGAN PERENCANAAN TATA RUANG 2005- 2025 DI KABUPATEN BOGOR
}

\section{The Dinamics of Landuse Change and Prediction 2025 Also Its Associations with Spatial Planning 2005-2025 in Bogor Regency}

\author{
Rahmi Fajarini1 ${ }^{*}$, Baba Barus ${ }^{2)}$, dan Dyah Retno Panuju ${ }^{2)}$ \\ 1) Alumni Program Studi Ilmu Perencanaan Wilayah, Sekolah Pascasarjana IPB, Jl. Raya Darmaga, Gedung Andi \\ Hakim Nasoetion Kampus IPB Darmaga Bogor 16680 \\ 2) Departemen Ilmu Tanah dan Sumberdaya Lahan, Fakultas Pertanian IPB, Jl. Meranti Kampus IPB Darmaga \\ Bogor 16680
}

\begin{abstract}
The demand for land increases triggered by population growth, development community structures and economy. On the other hand, supply of land is somewhat constant, thus it will lead to land conversion. This study aims to identify land use changes in Bogor Regency in 1989-2013 to determine factor affecting land use change in Bogor Regency to predict land use in 2025 and to assess its accuracy, and to evaluate the conformity of predicted land use with Spatial Plan of Bogor Regency 2005-2025. The highest rate of change was in cropland including wet agricultural land (paddy fields) and dry agricultural land (garden and upland). Total change of agricultural uses into the built-up area was 47,953 ha or 16.04\%. Factors increasing the change of agricultural land into non-agricultural uses are location permits in 2005, areal allocated for industrial area, and distance of land to road. Factors decreasing the change are slope (16-25\%), type of soil particularly Podzolik, and the distance of land to government center. Markov analysis generated prediction of land use in 2013 with an accuracy 80.49\%. Result of conformity analysis between actual landuse in 2013 and Spatial Plan Bogor Regency indicates a problem in an area as much as 63,822 ha (21.36\%), where the forest area reduced by $64.90 \%$ paddy field lowered by $20.68 \%$ and waterbody declined by 6.49\%. The result of conformity analysis between predicted landuse in 2025 and Spatial Plan Bogor Regency indicates potential problem related to spatial planning in Bogor Regency as much as 75,577 ha (25.29\%), where the forest area potentially reduced by $72.41 \%$, paddy field potentially lowered by $33.62 \%$, and waterbody potentially declined by 24.64\%. The result indicates an increase of unconformity from 2013 amounted to 11,856 ha (3.96\%).
\end{abstract}

Keywords: Binary logistic regression, landuse change, landuse modelling, Markov Chain

\begin{abstract}
ABSTRAK
Kebutuhan lahan selalu meningkat dipicu oleh pertumbuhan penduduk, perkembangan struktur masyarakat dan perekonomian, sementara penawaran terhadap lahan tidak pernah bertambah, sehingga cepat atau lambat kondisi tersebut akan menimbulkan konversi lahan. Penelitian bertujuan mengidentifikasi perubahan penggunaan lahan Kabupaten Bogor tahun 1989-2013, menentukan faktor-faktor penentu perubahan penggunaan lahan di Kabupaten Bogor, memprediksi penggunaan lahan tahun 2025 dan menguji akurasinya, serta mengevaluasi keselarasan prediksi penggunaan lahan tahun 2025 dengan Rencana Tata Ruang Wilayah Kabupaten Bogor 2005-2025. Lahan yang paling banyak berubah adalah lahan pertanian baik lahan pertanian basah (sawah) maupun lahan pertanian kering (kebun dan tegalan). Total areal pertanian yang berubah menjadi lahan terbangun sebesar 47,953 ha atau 16.04\% dari luas Kabupaten Bogor. Faktor-faktor yang meningkatkan perubahan penggunaan lahan pertanian menjadi non pertanian adalah izin lokasi tahun 2005, penetapan kawasan industri dalam kebijakan tata ruang, jarak ke/dari jalan kolektor, jarak ke/dari pusat aktivias ekonomi. Faktor - faktor yang menurunkan perubahan penggunaan lahan pertanian menjadi non pertanian adalah kelas lereng $(16-25 \%)$, jenis tanah podsolik, dan jarak ke/dari pusat pemerintahan kabupaten. Prediksi penggunaan lahan tahun 2013 memiliki nilai ketepatan $80.49 \%$ sehingga model digunakan dalam prediksi penggunaan lahan tahun 2025. Hasil analisis keselarasan RTRW 2005-2025 dengan penggunaan lahan aktual 2013 menunjukkan adanya ketidakselarasan yang dapat menjadi masalah tata ruang di Kabupaten Bogor 63,822 ha atau $21.36 \%$, dimana hutan hilang $64.90 \%$, pertanian lahan basah hilang $20.68 \%$ serta tubuh air hilang $6.49 \%$. Hasil analisis keselarasan RTRW 2005-2025 dengan penggunaan lahan hasil prediksi tahun 2025 menunjukkan adanya ketidakselarasan dengan alokasi ruang yang berpotensi menjadi permasalahan tata ruang sebesar 75,577 ha atau $25.29 \%$, dimana terdapat potensi berkurangnya hutan, pertanian lahan basah dan tubuh air masing-masing sebesar $72.41 \%, 33.62 \%, 24.64 \%$. Nilai tersebut menunjukkan adanya kenaikan ketidakselarasan dari tahun 2013 sebesar 11,856 ha atau 3.96\%.
\end{abstract}

Kata kunci: Regresi logistik biner, perubahan penggunaan lahan, model penggunaan lahan, Markov Chain 


\section{PENDAHULUAN}

Kebutuhan lahan meningkat dari waktu ke waktu dipicu oleh pertumbuhan penduduk, perkembangan struktur masyarakat dan perekonomian. Sementara lahan tersedia relatif tidak bertambah, sehingga kondisi tersebut berakibat pada alih fungsi lahan. Alih fungsi atau konversi lahan akan menjadi masalah apabila terjadi di lahan pertanian produktif. Konversi lahan pertanian akan menyebabkan penurunan produksi pangan dan kerugian lingkungan seperti berkurangnya ruang-ruang dengan fungsi konservasi (Pribadi et al., 2006)

Sebagai salah satu wilayah yang dengan Jakarta, Kabupaten Bogor mengalami perubahan yang sangat dinamis, baik dalam pemanfaatan ruang maupun sosial ekonomi dan kelembagaannya. Hal tersebut sejalan dengan hasil penelitian Trisasongko et al. (2009) yang menyatakan bahwa konversi lahan pertanian di wilayah Jabodetabek terjadi akibat adanya introduksi pembangunan jalan tol, sehingga memudahkan akses masyarakat dari Jakarta menuju wilayah sekeliling Jakarta. Mudahnya akses menuju Jakarta memunculkan fenomena komutasi yaitu bekerja di Jakarta namun tinggal di wilayah sekitarnya seperti Bogor, Depok, Tangerang dan Bekasi. Berdasarkan fakta tersebut, Kabupaten Bogor sangat berpotensi mengalami perubahan penggunaan lahan, khususnya perubahan lahan pertanian menjadi lahan terbangun.

Dinamika perubahan penggunaan lahan yang terjadi di Kabupaten Bogor seharusnya sejalan dengan Rencana Tata Ruang Wilayah (RTRW) Kabupaten Bogor, karena RTRW merupakan panduan alokasi ruang agar pembangunan suatu wilayah tidak melampaui daya dukungnya (Rustiadi et al., 2008). Apabila pembangunan wilayah dilakukan dengan melampaui daya dukung wilayah tersebut akan mengalami kerusakan secara ekologis sehingga prinsip pembangunan berkelanjutan tidak akan terwujud (Dewan dan Yamaguchi, 2009). Oleh karena itu dalam penelitian ini juga dilakukan analisis kesesuaian penggunaan lahan saat ini dengan Rencana Tata Ruang Wilayah Kabupaten Bogor dimana Kabupaten Bogor merupakan salah satu wilayah resapan air terbesar untuk wilayah-wilayah yang berada di bawahnya seperti Kota Bogor, Depok dan Jakarta. Dalam penelitian Hadi (2012), perubahan penggunaan lahan di Kabupaten Bogor dilihat dalam tiga titik tahun pengamatan yakni 1989, 2000 dan 2010 dan menggunakan model prediksi Clue-S, sementara dalam penelitian ini pengamatan dilakukan dalam enam titik tahun yakni 1989, 1995, 2001, 2006, 2009 dan 2013 dengan menggunakan model prediksi Markov sehingga diharapkan pola dinamika perubahan penggunaan lahannya terlihat lebih detil.

Tujuan penelitian adalah adalah sebagai berikut: (1) Mengidentifikasi perubahan dan pola penggunaan lahan di Kabupaten Bogor tahun 1989-2013, (2) Menentukan faktor-faktor penentu perubahan penggunaan lahan di Kabupaten Bogor, (3) Memprediksi penggunaan lahan tahun 2025, (4) Mengevaluasi keselarasan penggunaan lahan tahun 2013 dan 2025 dengan Rencana Tata Ruang Wilayah Kabupaten Bogor 2005-2025 serta melihat potensi masalahnya.

\section{BAHAN DAN METODE}

Lokasi penelitian adalah Kabupaten Bogor Jawa Barat yang secara geografis terletak pada $6^{\circ} 18^{\prime} 6^{\circ} 47^{\prime} 10 \mathrm{LS}$ dan $106^{\circ} 23^{\prime} 45-107^{\circ} 13$ '30 BT. Lokasi ini dipilih karena Kabupaten Bogor merupakan wilayah penyangga DKI Jakarta dan sekitarnya, sehingga diperkirakan akan mengalami perubahan penggunaan lahan yang nyata.

Data utama dalam penelitian ini adalah citra Landsat Kabupaten Bogor tahun 1989, 1995, 2001, 2006, 2009 dan 2013. Sementara data pendukung untuk mengkaji faktor penentu perubahan penggunaan lahan terdiri dari data Potensi Desa, Kabupaten Bogor Dalam Angka, Peta Tanah, Peta Lereng, Peta Pola Ruang dan Peta Hak Ijin Usaha. Data sekunder diperoleh dari Badan Pusat Statistik Kabupaten Bogor, Badan Perencanaan Pembangunan Daerah Kabupaten Bogor, Pusat Pengkajian Perencanaan dan Pengembangan Wilayah (P4W), Divisi Perencanaan dan Pengembangan Wilayah Departemen Ilmu Tanah dan Sumberdaya Lahan (ITSL) dan Badan Informasi Geospasial (BIG).

\section{Analisis Dinamika Perubahan Penggunaan Lahan}

Analisis ini dilakukan dalam dua tahap. Pertama, tahap persiapan yang meliputi aktivitas pengunduhan citra landsat, penggabungan kanal citra (layer stack), pemotongan citra, koreksi geometri, klasifikasi visual dan pengecekan lapang. Citra landsat diunduh dari http://glovis.usgs.gov/ yang berada pada path/row 122/64 dan 122/65 dengan liputan awan yang minimum pada tahun 1995, 2001, 2006, 2009 dan 2013 sedangkan penggunaan lahan tahun 1989 diambil dari Peta Rupa Bumi Indonesia. Citra yang telah diunduh kemudian digabung dan dipotong sesuai batas luar peta administrasi Kabupaten Bogor untuk memfokuskan pada lokasi penelitian. Selanjutnya citra dikoreksi geometri dengan menggunakan acuan peta dasar (sungai dan jalan) agar memiliki koordinat yang sama.

Setelah memiliki koordinat yang sama dengan peta dasar, dilakukan klasifikasi visual berdasarkan interpretasi sesuai ukuran, pola, rona, tekstur dan warna pada citra. Klasifikasi penggunaan lahan yang diamati adalah hutan, kebun, lahan terbangun, sawah, tegalan, tubuh air dan lainlain. Klasifikasi dilakukan pada seluruh citra tahun pengamatan sehingga diperoleh peta penggunaan lahan tahun 1989, 1995, 2001, 2006, 2009 dan 2013. Tahap yang kedua dalam analisis ini adalah tahap proses analisis. Metode yag dilakukan dalam tahapan ini adalah dengan menumpangtindihkan (overlay) peta penggunaan lahan semua tahun pengamatan sehingga dihasilkan suatu matriks transisi perubahan penggunaan lahan dari tahun ke tahun.

\section{Analisis Faktor-Faktor Penentu Perubahan Penggunaan Lahan}

Analisis dilakukan dengan menggunakan metode regresi logistik biner, karena variabel respon yang digunakan bersifat kategorik dan dikotomi ( $Y=0$ Jika tidak terjadi perubahan; $Y=1$ Jika terjadi perubahan penggunaan lahan pada poligon tersebut). Analisis faktor yang mempengaruhi perubahan penggunaan lahan melibatkan peta penggunaan lahan, peta administrasi, peta RTRW 
2005-2025, peta jenis tanah, peta kemiringan lereng, peta ijin lokasi tahun 2005 dan 2011 serta data statistik seperti laju pertumbuhan penduduk, laju pertumbuhan fasilitas, jarak terhadap jalan terdekat, jarak ke pusat pemerintahan kabupaten dan kota, serta jarak ke pusat aktivitas ekonomi.

Perubahan penggunaan lahan yang dianalisis yaitu perubahan penggunaan lahan pertanian menjadi lahan non pertanian pada periode 1989 sampai 2013. Analisis dilakukan dengan menggunakan metode regresi logistik biner menggunakan perangkat lunak SPSS yang dapat menganalisis nilai kategori dan non kategori. Persamaan regresi logistik yang digunakan adalah:

$$
\begin{aligned}
& \log \left(\frac{\mathrm{P}_{1}}{1-\mathrm{P}_{1}}\right)=\beta_{0}+\beta_{1} X_{1,1}+\beta_{2} X_{2,1}+\cdots+\beta_{n} X_{n, 1} \\
& \text { dimana: } \\
& P_{1} \quad=\text { Nilai peluang untuk peubah tetap ke } 1 \\
& \beta_{0} \quad=\text { Konstanta } \\
& \beta_{1-n} \quad=\text { Nilai koefisien untuk peubah bebas ke } 1 \\
& \text { sampai } n \\
& X_{1-n, 1}=\text { Peubah bebas ke } 1 \text { sampai } \mathrm{n} \text {, pada } \\
& \text { peubah tetap ke } 1 \\
& \mathrm{n} \quad=\text { Jumlah variebel } \\
& X_{1}, X_{2} \ldots X_{n} \quad=\text { Faktor yang diduga mempengaruhi } \\
& \text { proses perubahan penggunaan lahan } \\
& \text { pertanian menjadi lahan non pertanian }
\end{aligned}
$$

\begin{tabular}{|c|c|}
\hline Peubah Respon (Y) & Peubah Penjelas $(\mathrm{X})$ \\
\hline \multirow[t]{10}{*}{$\mathrm{Y}=$ Perubahan Lahan Pertanian menjadi Lahan Non-pertanian } & X1: Kepadatan Penduduk (jumlah orang $\mathrm{km}^{-2}$ ) \\
\hline & X2: Laju Pertumbuhan Fasilitas (Jumlah dan Jenis Fasilitas ekonomi) \\
\hline & X3: Ijin Tahun 2005 \\
\hline & X4: Ijin Tahun 2011 \\
\hline & X5: Kelas Lereng $(1=(0-8) \%, 2=(9-15) \%, 3=(16-25) \%), 4=(>40) \%$ \\
\hline & $\begin{array}{l}\text { X6: Kelas Pola Ruang (1=Kawasan Lindung, 2=Kawasan Perkebunan, } 3=\text { Kawasan } \\
\text { Pertanian, 4=Kawasan Industri, 5=Kawasan Permukiman) } \\
\text { X7: Kelas Tanah (1= Aluvial \& Latosol; 2= Andosol; } 3=\text { Grumusoli; } 4=\text { Podsolik; 5= } \\
\text { Regosol) }\end{array}$ \\
\hline & X8: Jarak ke Jalan Kolektor \\
\hline & X9: Jarak ke Jalan Tol \\
\hline & X11: Jarak ke Pusat Pemerintahan Kabupaten \\
\hline & X12: Jarak ke Pusat Pemerintahan Kota \\
\hline
\end{tabular}

Tabel 1. Variabel dalam pendugaan penentu perubahan penggunaan lahan

\section{Prediksi Penggunaan Lahan Tahun 2025 serta Evaluasi Kesesuaiannya dengan RTRW Kabupaten Bogor Tahun 2005-2025}

Metode ini mengasumsikan bahwa pola perubahan penggunaan lahan di masa yang akan datang serupa dengan pola perubahan penggunaan lahan masa yang telah lalu (Deng et al., 2009). Data yang digunakan dalam analisis ini berupa data raster (pixel), dengan menggunakan perangkat lunak IDRISI Taiga. Selain mendapatkan prediksi perubahan penggunaan lahan tahun 2013 dan 2025, dalam penelitian ini juga dilakukan akurasi prediksi Markov. Data yang digunakan untuk memprediksi penggunaan lahan tahun 2025 dibangun dari data penggunaan lahan tahun 1989-2013. Setelah mendapatkan peta penggunaan lahan hasil prediksi Markov tahun 2013, kemudian dilakukan analisis akurasi dengan penggunaan lahan riil yaitu peta penggunaan lahan tahun 2013 yang telah direklasifikasi. Setelah diuji akurasi dan validasinya cukup tinggi dan konsisten, maka model tersebut dapat digunakan untuk estimasi penggunaan lahan tahun 2025.

Pengujian tingkat akurasi hasil Markov dengan penggunaan lahan aktual 2013 dilakukan dengan menggunakan data penggunaan lahan tahun 2013. Akurasi dihitung dengan mencari selisih luas penggunaan hasil dugaan Markov Chain dengan penggunaan lahan aktual tahun 2013. Semakin kecil selisih atau perbedaan alokasi ruang dengan riil penggunaan lahan tahun 2025, maka tingkat ketercapaian RTRW 2005-2025 semakin tinggi.

\section{HASIL DAN PEMBAHASAN}

\section{Dinamika Perubahan Penggunaan Lahan di Kabupaten Bogor}

Hasil penelitian menunjukkan bahwa Kabupaten Bogor dari titik tahun 1989, 1995, 2001, 2006, 2009 hingga 2013 mengalami perubahan penggunaan lahan yang sangat dinamis. Penggunaan lahan yang paling besar perubahannya adalah lahan terbangun dimana jumlahnya bertambah 48,232 ha. Pertambahan luas lahan terbangun yang signifikan ini merupakan hasil konversi lahan sawah, kebun, dan hutan dimana sawah mengalami penurunan sebesar 24,180 ha, kebun mengalami penurunan sebesar 22,081 ha. dan hutan mengalami penurunan sebesar 5,825 ha. Dinamika dan pola perubahan penggunaan lahan Kabupaten Bogor tahun 1989-2013 disajikan pada Gambar 1 dan Gambar 2. 


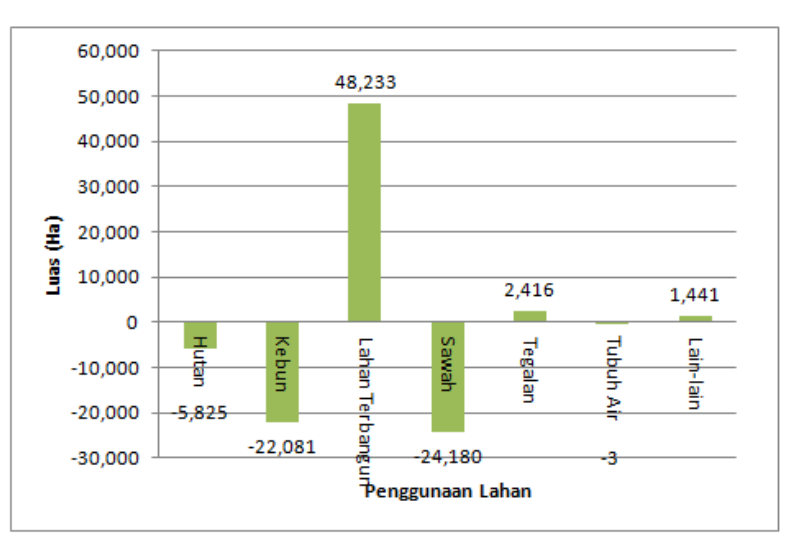

Gambar 1. Dinamika perubahan penggunaan lahan Kabupaten Bogor tahun 1989-2013

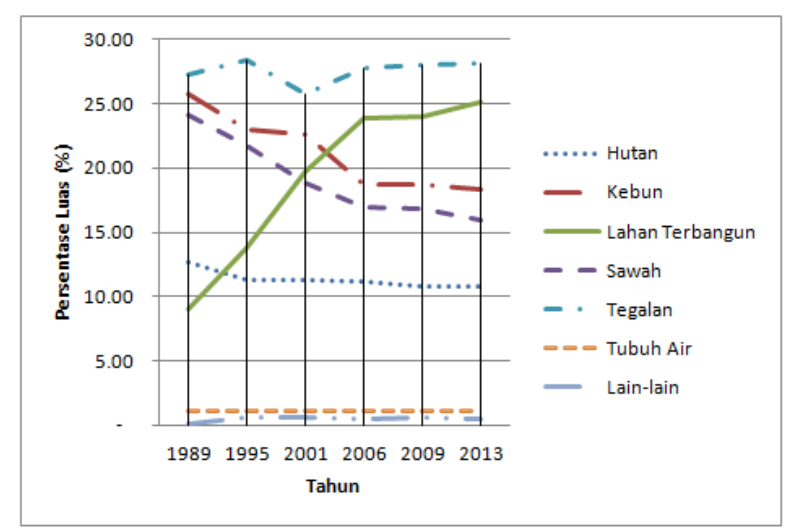

Gambar 2. Pola dinamika perubahan penggunaan lahan di Kabupaten Bogor
Berdasarkan pola perubahan penggunaan lahan yang muncul diantara enam titik tahun pengamatan, pola perubahan yang signifikan selalu terjadi pada rentang tahun 1995-2001 di setiap penggunaan lahannya. Hal ini diduga berkaitan dengan krisis ekonomi yang terjadi di Indonesia pada rentang tahun tersebut. Krisis moneter tersebut menyebabkan fenomena penjualan aset properti yang dimiliki baik berupa rumah maupun tanah dengan harga murah, di sisi lain sekelompok kecil pemilik modal membeli properti sebanyak-banyaknya. Oleh sebab itu pada rentang titik tahun 1995-2001 terjadi konversi penggunaan lahan sawah, kebun dan lahan terbangun. Hal ini sejalan dengan hasil penelitian Ilham et al. (2005) yang menyatakan bahwa tekanan ekonomi pada saat krisis ekonomi menyebabkan banyak petani menjual sawah untuk memenuhi kebutuhan hidup. Dampaknya secara umum meningkatkan konversi lahan sawah dan memusatnya penguasaan lahan pada pihak-pihak tertentu. Setelah mengetahui pola dinamika perubahan penggunaan lahan, matriks transisi perubahan penggunaan lahan dapat dibangun untuk mengetahui penggunaan lahan tahun awal dan penggunaan lahan tahun akhir, apakah mengalami perubahan atau tetap. Matriks transisi perubahan penggunaan lahan di Kabupaten Bogor tahun 1989-2013 disajikan pada Tabel 2. Dari matriks transisi dapat dilihat bahwa perubahan lahan pertanian yang meliputi kebun, sawah dan tegalan di tahun 1989 menjadi lahan terbangun di tahun 2013 merupakan alih fungsi lahan yang paling dominan yakni sebesar 47,953 ha atau $16.05 \%$ dari total luas Kabupaten Bogor.

Tabel 2. Matriks transisi perubahan penggunaan lahan tahun 1989-2013

\begin{tabular}{lrrrrrrrr}
\hline \multirow{2}{*}{$\begin{array}{c}\text { Penggunaan Lahan } \\
1989\end{array}$} & Kutan & Kebun & $\begin{array}{r}\text { Lahan } \\
\text { Terbangun }\end{array}$ & Lain-lain & Sawah & Tegalan & Tubuh Air & Total \\
\cline { 2 - 9 } & 32,066 & 1,737 & 245 & - & 270 & 3,584 & - & 37,903 \\
Hutan & 1 & 52,966 & 9,857 & 374 & - & 13,662 & - & 76,861 \\
Kebun & - & & 27,005 & - & - & - & - & 27,005 \\
Lahan Terbangun & - & & 32 & 108 & - & - & - & 140 \\
Lain-lain & - & 63 & 20,338 & 185 & 47,545 & 3,865 & - & 71,995 \\
Sawah & 10 & 13 & 17,758 & 914 & - & 62,858 & - & 81,553 \\
Tegalan & - & & 3 & - & - & - & 3,338 & 3,340 \\
Tubuh Air & 32,077 & 54,780 & 75,238 & 1,581 & 47,815 & 83,969 & 3,338 & 298,797 \\
\hline Total & & & & & & &
\end{tabular}

Konversi lahan sawah dan tegalan menjadi lahan terbangun merupakan yang terbesar diantara jenis perubahan penggunaan lahan (pada periode 1989-2013) di Kabupaten Bogor. Hal ini dikarenakan kebanyakan sawah dan tegalan berada pada lokasi dengan lereng yang landai serta berada dekat dengan permukiman dan pusat fasilitas, mudah dijangkau sehingga lebih disukai sebagai lokasi pengembangan aktifitas. Konversi kedua penggunaan lahan ini perlu mendapat perhatian lebih dari pemerintah baik pusat maupun daerah terkait dengan isu ketahanan pangan. Salah satu bentuk perlindungan pemerintah terhadap lahan pertanian adalah lahirnya Undang-Undang No. 41 Tahun 2009 tentang Perlindungan Lahan Pertanian Pangan Berkelanjutan (LP2B) menjelaskan bahwa lahan sawah atau hortikultura dilindungi peruntukannya, sehingga keberadaannya tidak boleh diganggu gugat sejak ditetapkan menjadi lahan pertanian dalam Rencana Tata Rang Wilayah hingga 20 tahun ke depan (jangka waktu RTRW). Sebaran perubahan penggunaan lahan dari tahun ke tahun pengamatan disajikan pada Gambar 3. Dari gambar tersebut dapat dilihat perubahan paling nyata terjadi pada rentang waktu 1989-1995 dan 1995-2001 dan pola sebarannya merata hampir di semua wilayah Kabupaten Bogor. Dari gambar tersebut dapat dilihat bahwa lahan yang paling banyak berubah adalah tegalan dan sawah menjadi penggunaan lahan lain khususnya lahan terbangun. 


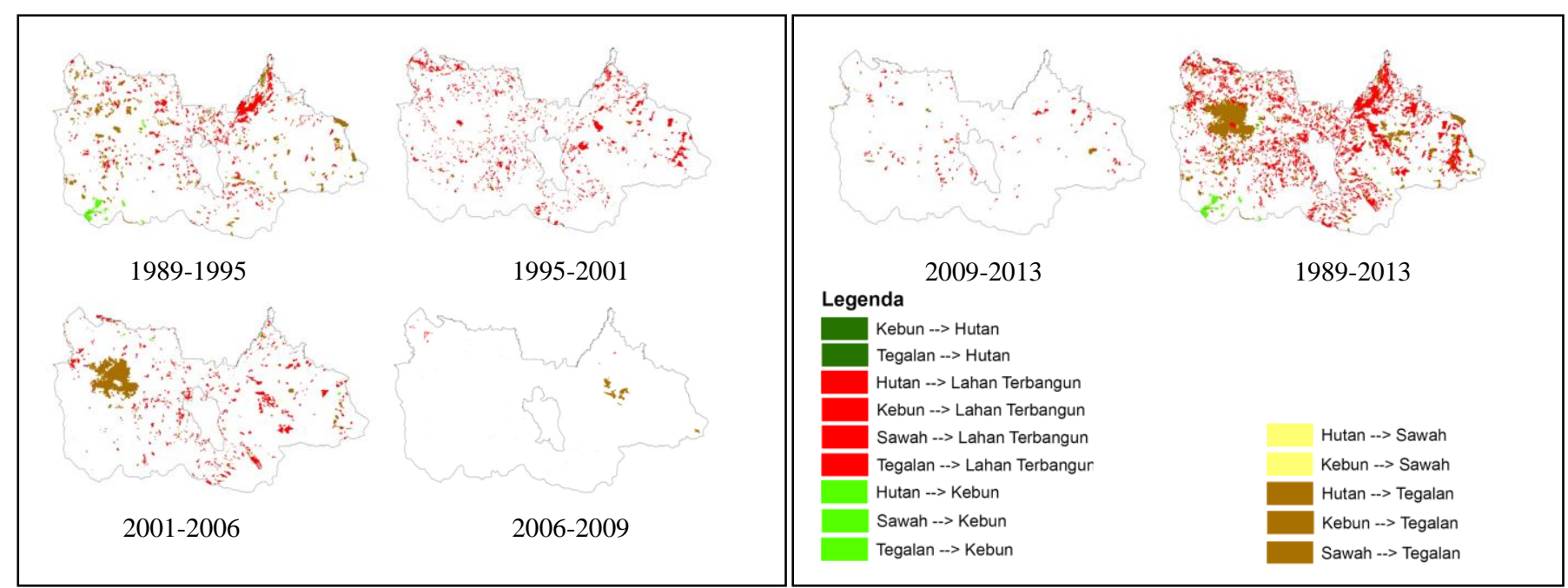

Gambar 3. Perubahan penggunaan lahan Kabupaten Bogor tahun 1989-2013

Faktor-faktor yang Mempengaruhi Perubahan Penggunaan Lahan di Kabupaten Bogor Tahun 19892013

Faktor-faktor yang berpeluang meningkatkan konversi lahan pertanian menjadi non pertanian adalah izin lokasi tahun 2005, penetapan kawasan industri dalam RTRW, jarak ke jalan kolektor, dan jarak ke pusat aktivias ekonomi. Hasil analisis tersebut menunjukkan bahwa Pemerintah Kabupaten Bogor tahun 2005 mengeluarkan ijin lokasi pembangunan kawasan industri. Hasil analisis diperkuat dengan tulisan Firman (2004) yang menyatakan bahwa pajak tanah bersama-sama dengan izin lokasi dan izin bangunan dianggap tidak efektif mengendalikan konversi lahan, karena dianggap sebagai instrumen untuk memperoleh tambahan pendapatan negara. Akibatnya justru menjadi aspek legal yang mendorong terjadinya konversi lahan. Oleh karena itu dapat disimpulkan bahwa kebijakan investasi dan pemanfaatan lahan selama ini belum memprioritaskan kepentingan umum.

Tabel 3. Ringkasan koefisien hasil analisis regresi logistik biner penentu perubahan penggunaan lahan pertanian menjadi non pertanian tahun 1989-2013

\begin{tabular}{|c|c|c|c|c|c|}
\hline Variabel & B & Statistik Wald & Sig & & Odds Ratio \\
\hline Kepadatan & 11.980 & 0.207 & 0.649 & & 159588.6 \\
\hline Laju Pertumbuhan Fasilitas & 120.871 & 0.029 & 0.865 & & $3.12 \mathrm{E}+52$ \\
\hline Izin Lokasi tahun 2005 & 0.486 & 11.302 & 0.001 & $*$ & 1.63 \\
\hline Kelas Lereng & & 36.254 & 0.000 & & \\
\hline$-(0-8) \%$ & 0.276 & 0.123 & 0.725 & & 1.32 \\
\hline$-(8-16) \%$ & -0.538 & 0.482 & 0.488 & & 0.58 \\
\hline$-(16-25) \%$ & -1.884 & 6.509 & 0.011 & $*$ & 0.15 \\
\hline Kelas Pola Ruang & & 9.245 & 0.055 & & \\
\hline - Kasawan Lindung & -0.781 & 2.206 & 0.137 & & 0.46 \\
\hline - Kawasan Perkebunan & -0.511 & 1.573 & 0.210 & & 0.60 \\
\hline - Kawasan Pertanian & -0.020 & 0.015 & 0.901 & & 0.98 \\
\hline - Kawasan Industri & 0.702 & 5.351 & 0.021 & $*$ & 2.02 \\
\hline Jenis Tanah & & 22.522 & 0.000 & & \\
\hline - Aluvial dan Latosol & -0.541 & 0.725 & 0.395 & & 0.58 \\
\hline - Andosol & 1.049 & 1.050 & 0.306 & & 2.85 \\
\hline - Grumusol & -0.903 & 1.586 & 0.208 & & 0.41 \\
\hline - Podsolik & -1.696 & 5.892 & 0.015 & $*$ & 0.18 \\
\hline Jarak ke Jalan Kolektor & 0.111 & 29.791 & 0.000 & $*$ & 1.12 \\
\hline Jarak ke Pusat Aktivitas Ekonomi & 0.070 & 13.831 & 0.000 & $*$ & 1.07 \\
\hline Jarak ke Pusat Pemerintahan Kabupaten & -0.087 & 20.877 & 0.000 & $*$ & 0.92 \\
\hline
\end{tabular}


Faktor kedua yang signifikan meningkatkan perubahan penggunaan lahan adalah kebijakan tata ruang kawasan industri dalam RTRW Kabupaten Bogor 20052025. Hal ini dapat dimengerti karena perkembangan suatu kawasan perkotan dan industri memerlukan lahan yang luas. Hasil ini juga ditunjang oleh penelitian Firman (2004) yang menyatakan bahwa kebijakan investasi yang dipicu oleh pertumbuhan ekonomi pada dasawarsa 1980-an dan 1990-an telah mendorong investor asing dan domestik menanamkan usahanya sehingga meningkatkan permintaan lahan untuk industri. Kemudahan yang diberikan kepada para pengembang sering mengabaikan hak-hak pemilik tanah dan mendorong terjadinya spekulasi dalam jual beli tanah. Hal ini merupakan salah satu alasan tidak terkendalinya konversi lahan pertanian menjadi lahan perkotaan dan industri. Faktor berikutnya yang berpengaruh signifikan terhadap meningkatnya perubahan penggunaan lahan adalah jarak dari/ke jalan kolektor dan jarak dari/ke pusat aktivitas ekonomi. Hal ini menunjukkan bahwa semakin dekat jarak dari/ke jalan kolektor dan pusat aktivitas ekonomi, maka semakin tinggi peluang terjadinya perubahan penggunaan lahan. Peningkatan peluang perubahan lahan tersebut diduga terkait dengan nilai lahan yang tinggi di lokasi tersebut sehingga mendorong pemilik lahan merubah fungsi lahan menjadi penggunaan lahan yang lebih komersil.

Faktor-faktor yang berpeluang menurunkan konversi lahan pertanian menjadi lahan non-pertanian adalah kelas lereng $(16-25 \%)$, jenis tanah Podsolik, dan jarak ke pusat pemerintahan kabupaten. Hasil analisis tersebut menunjukkan bahwa lahan yang memiliki kemiringan lereng $(16-25 \%)$ memiliki kecenderungan menurunkan perubahan penggunaan lahan. Lahan dengan kemiringan lereng tersebut termasuk dataran curam yang membuat penggunaan lahannya terbatas, sehingga menurunkan keinginan pemilik lahan mengubah penggunaan lahan untuk kegiatan produktif.

Jenis tanah podsolik memiliki karakteristik kesuburan hingga sedang, warna merah atau kuning, memiliki tekstur lempung atau berpasir, memiliki $\mathrm{pH}$ rendah, serta memiliki kandungan unsur aluminium dan besi yang tinggi. Dari beberapa karakteristik tersebut tanah
Podsolik dapat dikategorikan sebagai tanah yang memiliki kesuburan rendah, sehingga penggunaannya untuk pertanian harus memerlukan perlakuan khusus. Disamping memiliki kesuburan yang rendah, tanah Podsolik juga memiliki tekstur berpasir atau lempung dengan daya simpan air sangat rendah sehingga mudah mengalami kekeringan. Oleh sebab itu, Keterbatasan penggunaan lahan pada jenis tanah Podsolik tersebut cenderung menurunkan peluang perubahan penggunaan lahan seperti ditunjukkan dalam hasil analisis statistik.

Faktor yang berpengaruh menurunkan peluang perubahan penggunaan lahan pertanian menjadi lahan nonpertanian selanjutnya adalah jarak ke pusat pemerintahan kabupaten. Hal ini menjelaskan bahwa semakin dekat jarak ke pusat pemerintahan kabupaten, potensi luas pertanian yang terkonversi semakin kecil. Hal ini terjadi karena pusat pemerintahan memiliki daya tarik aglomeratif. Namun ada kecenderungan arus konversi lahan pertanian di sekitar pusat pemerintahan relatif jenuh karena sudah terjadi pada periode sebelumnya. Di sisi lain, berkembangnya isu kota hijau dan berkelanjutan menggeser cara pandang pembangunan yang ekspansif di perkotaan.

\section{Pemodelan dan Prediksi Penggunaan Lahan Tahun 2013 dan Tahun 2025 serta Keselarasannya dengan RTRW 2005-2025}

Dalam pemodelan prediksi penggunaan lahan tahun 2013 dihasilkan nilai akurasi sebesar $80.49 \%$. Nilai akurasi yang cukup tinggi mengijinkan analisis lanjutan untuk memprediksi penggunaan lahan tahun mendatang, sehingga dapat langsung diaplikasikan dalam mengestimasi penggunaan lahan tahun 2025 yang hasilnya disajikan pada Gambar 4. Keselarasan antara alokasi ruang RTRW Kabupaten Bogor 2005-2025 dengan hasil estimasi penggunaan lahan Kabupaten Bogor tahun 2025 dapat dilihat pada Tabel 4.

Berdasarkan Tabel 4, terdapat beberapa ketidakselarasan antara RTRW 2005-2025 dengan prediksi penggunaan lahan 2025 sehingga akan menyebabkan potensi permasalahan tata ruang (Tabel 5).

Tabel 4. Evaluasi keselarasan RTRW Kabupaten Bogor 2005-2025 dengan estimasi penggunaan lahan 2025

\begin{tabular}{|c|c|c|c|c|c|c|c|c|}
\hline \multirow[b]{2}{*}{ No } & \multirow[b]{2}{*}{ RTRW 2005-2025 } & \multicolumn{7}{|c|}{ Prediksi Penggunaan Lahan 2025 (ha) } \\
\hline & & Hutan & Kebun & $\begin{array}{c}\text { Lahan } \\
\text { Terbangun }\end{array}$ & Sawah & Tegalan & Tubuh Air & $\begin{array}{l}\text { Lain- } \\
\text { lain }\end{array}$ \\
\hline 1 & Kawasan Hutan Lindung \& Konservasi & 20,105 & 6,098 & 5,808 & 1,360 & 16,911 & 92 & 397 \\
\hline 2 & Kawasan Hutan Produksi & 3,117 & 3,112 & 8,722 & 2,173 & 16,601 & 184 & 489 \\
\hline 3 & Kawasan Industri & 68 & 261 & 3,088 & 440 & 590 & 121 & 145 \\
\hline 4 & Kawasan Perkebunan & 203 & 3,073 & 2,778 & 368 & 3,311 & 19 & 102 \\
\hline 5 & Kawasan Permukiman & 1,476 & 13,194 & 52,449 & 13,615 & 18,663 & 2,328 & 2,405 \\
\hline 6 & Kawasan Pertanian Lahan Basah & 363 & 7,347 & 13,412 & 10,169 & 7,371 & 731 & 494 \\
\hline 7 & Kawasan Pertanian Lahan Kering & 1,142 & 9,119 & 17,188 & 6,089 & 18,189 & 445 & 866 \\
\hline 8 & Tubuh Air & 5 & 179 & 494 & 378 & 252 & 687 & 10 \\
\hline
\end{tabular}

Tabel 4 dan Tabel 5 menjelaskan terdapat 75,577 ha atau $25.29 \%$ ketidakselarasan RTRW dengan prediksi penggunaan lahan tahun 2025 yang berpotensi menjadi permasalahan tata ruang di Kabupaten Bogor pada tahun 2025. Adapun potensi masalah tersebut meliputi potensi konflik penguasaan lahan di kawasan hutan karena teridentifikasinya penggunaan lahan non hutan pada kawasan hutan. Penggunaan lahan non hutan tersebut berupa kebun $(3.08 \%)$, lahan terbangun $(4.86 \%)$, sawah $(1.18 \%)$, tegalan $(11.22 \%)$ dan lain-lain $(0.30 \%)$. Hal 
tersebut melanggar peraturan tata ruang mengenai kawasan hutan, dimana kawasan hutan merupakan suatu wilayah tertentu yang ditunjuk dan/atau ditetapkan oleh pemerintah untuk dipertahankan keberadaannya sebagai hutan tetap yang terdiri dari hutan konservasi, hutan lindung, hutan produksi terbatas, dan hutan produksi tetap. Hal ini didukung aspek legal berupa Peraturan Menteri Kehutanan Republik Indonesia Nomor P. 33 tahun 2010 yang menyatakan bahwa satu-satunya hutan yang dapat dialihfungsikan menjadi kegiatan pembangunan diluar kehutanan adalah kawasan hutan produksi konversi (HPK), sementara RTRW Kabupaten Bogor 2005-2025 tidak mengalokasikan kawasan hutan produksi konversi (HPK). Oleh sebab itu, pada tahun 2025 terdapat potensi kehilangan fungsi hutan sebesar 61,671 ha atau $72.41 \%$ dari total luas kawasan hutan dalam RTRW. Kehilangan fungsi hutan tersebut terdiri dari berkurangnya kawasan hutan lindung dan konservasi sebesar 30,574 ha atau $35.90 \%$ serta berkurangnya kawasan hutan produksi (terbatas dan tetap) sebesar 31,097 ha atau $36.51 \%$.
Kondisi ini mengancam fungsi hutan sebagai kawasan lindung dan konservasi dan sebagai daerah resapan air yang menaungi dan melindungi wilayah-wilayah di bawah Kabupaten Bogor seperti Kota Bogor, Tangerang, Depok dan DKI Jakarta. Akibatnya dapat meningkatkan peluang terjadinya bencana banjir saat musim hujan dan bencana kekeringan saat musim kemarau.

Tabel 5. Potensi masalah penataan ruang di Kabupaten Bogor tahun 2025

\begin{tabular}{llrr}
\hline & & \multicolumn{2}{c}{ Luas } \\
\cline { 3 - 4 } No & Potensi Masalah Penataan Ruang tahun 2025 & \multicolumn{1}{c}{ ha } \\
\hline & & 9,211 & 3.08 \\
2 & Hutan --> Kebun & 14,530 & 4.86 \\
3 & Hutan --> Lahan Terbangun & 3,533 & 1.18 \\
4 & Hutan --> Sawah & 33,512 & 11.22 \\
5 & Hutan --> Tegalan --> Lain-lain & 886 & 0.30 \\
6 & Pertanian Lahan Basah --> Lahan Terbangun & 13,412 & 4.49 \\
7 & Tubuh Air --> Lahan Terbangun & 494 & 0.17 \\
\hline \multicolumn{2}{c}{ Jumlah } & 75,577 & 25.29 \\
\hline
\end{tabular}

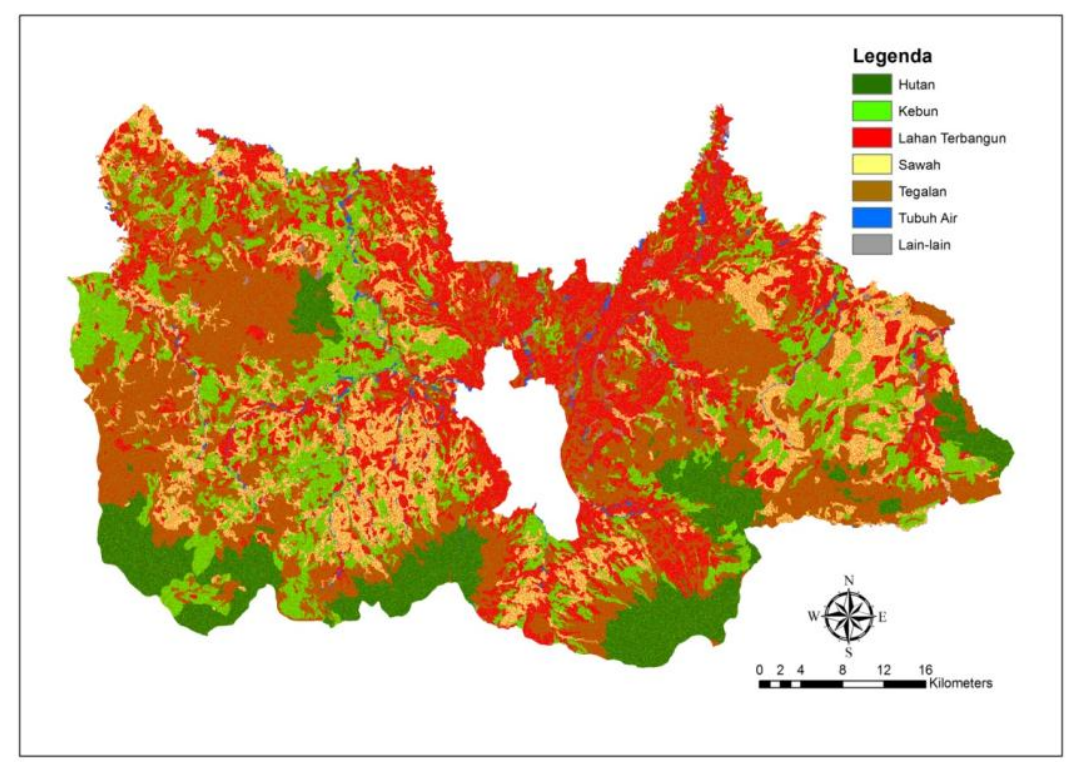

Gambar 4. Estimasi penggunaan lahan tahun 2025 berbasis Markov Chain

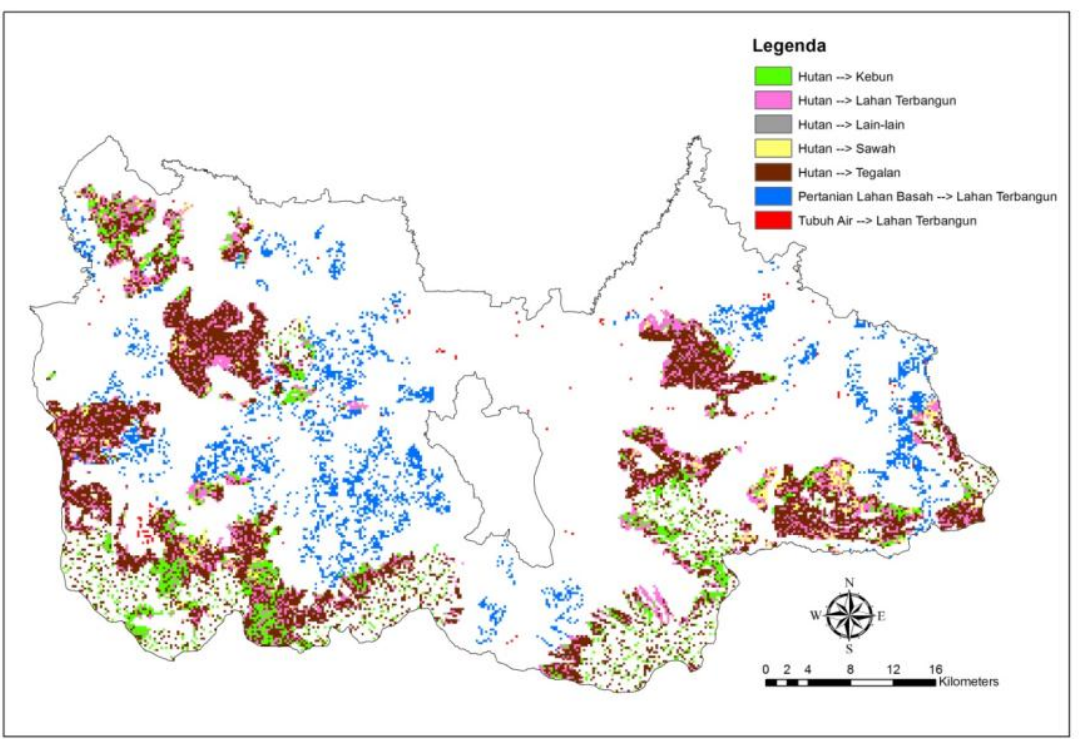

Gambar 5. Sebaran potensi masalah penataan ruang di Kabupaten Bogor tahun 2025 
Selain kawasan hutan, potensi masalah tata ruang di Kabupaten Bogor pada tahun 2025 adalah ketidakselarasan pada kawasan lahan pertanian basah yang dalam penggunaan lahannya diduga akan terkonversi menjadi lahan terbangun sebesar 13,412 ha atau $4.49 \%$ dari total luas Kabupaten Bogor. Hal ini menunjukkan bahwa Kabupaten Bogor berpotensi kehilangan lahan sawah sebesar 33.62\% dari alokasi yang ditetapkan dalam RTRW. Jika prediksi tersebut benar, maka dapat mengancam ketahanan pangan sebagaimana penelitian yang dilakukan oleh Irawan dan Friyatno (2002). Ketidakselarasan yang menyebabkan potensi masalah tata ruang berikutnya adalah lahan yang dialokasikan sebaai tubuh air akan dimanfaatkan sebagai lahan terbangun yakni sebesar 494 ha atau $0.17 \%$ dari total luas Kabupaten Bogor. Hal ini mengindikasikan bahwa pada tahun 2025 24.64\% dari total luas kawasan tubuh air yang dialokasikan akan digunakan untuk lahan terbangun. Seperti halnya hutan, tubuh air memiliki fungsi ekologis bagi suatu wilayah, yakni sebagai tempat penampung air sehingga dapat menjaga ketersediaan air tanah, baik di wilayah-wilayah sekitar lokasi tubuh air maupun wilayah-wilayah yang lebih jauh. Adapun sebaran spasial dari potensi permasalahan di Kabupaten Bogor tahun 2025 dapat dilihat pada Gambar 5.

Gambar 5 memperlihatkan sebaran spasial potensi permasalahan penataan ruang di Kabupaten Bogor tahun 2025. Hasil prediksi Markov tersebut merupakan potensi masalah yang akan terjadi apabila tidak ada perubahan kebijakan tata ruang yang dilakukan oleh pemerintah setempat. Tanpa ada induksi kebijakan dari pemerintah setempat, peluang terjadinya berbagai isu terkait penataan ruang tersebut cukup tinggi. Oleh sebab itu untuk menghindari potensi permasalahan di masa mendatang diharapkan pemerintahan Kabupaten Bogor dapat merubah kebijakan tata ruang, baik dalam tahap perencanaan, pemanfaatan maupun pengendalian. Hal tersebut akan lebih menjamin terwujudnya pemanfaatan ruang aktual dapat sejalan dengan rencana tata ruang wilayah dengan tetap mempertimbangkan fungsi ekologis wilayahnya.

\section{SIMPULAN}

Kabupaten Bogor dari tahun 1989 hingga 2013 mengalami perubahan penggunaan lahan yang dinamik. Lahan yang paling banyak berubah adalah lahan pertanian (sawah, kebun, tegalan) dengan total berubah menjadi lahan terbangun sebesar 47,953 ha atau $16.04 \%$ dari luas Kabupaten Bogor, dimana pola perubahan yang signifikan terjadi pada rentang tahun 1995-2001.

Faktor-faktor yang meningkatkan perubahan penggunaan lahan pertanian menjadi non pertanian adalah ijin lokasi tahun 2005, penetapan kawasan industri dalan RTRW, semakin dekat jarak ke/dari jalan kolektor, dan semakin dekat jarak ke/dari pusat aktivitas ekonomi. Faktor-faktor menurunkan perubahan penggunaan lahan pertanian menjadi non pertanian adalah adalah kelas lereng $(16-25 \%)$, jenis tanah Podsolik, dan semakin dekat jarak ke/dari pusat pemerintahan kabupaten.
Model spasial penggunaan lahan Markov dapat digunakan untuk memprediksi penggunaan lahan masa mendatang dengan tingkat ketelitian $80.49 \%$. Hasil analisis keselarasan RTRW 2005-2025 dengan penggunaan lahan hasil prediksi tahun 2025 menunjukkan adanya ketidakselarasan dengan alokasi ruang yang berpotensi menjadi permasalahan tata ruang sebesar 75,577 ha atau $25.29 \%$, dengan rincian potensi kehilangan fungsi hutan, fungsi pertanian lahan basah dan fungsi tubuh air masingmasing sebesar $72.41 \%, 33.62 \%$, dan $24.64 \%$. Ada kecenderungan kenaikan ketidakselarasan dari tahun 2013 sebesar 11,856 ha atau $3.96 \%$ yang mengindikasikan potensi masalah tata ruang pada tahun-tahun mendatang.

\section{DAFTAR PUSTAKA}

Deng, J.S., K. Wang, Y. Hong, and J.G. Qi. 2009. Spatio temporal dynamics and evolution of land use change and landscape pattern in response to rapid urbanization. Landscape and Urban Planning, 92: 187-198.

Dewan, A.M., and Y. Yamaguchi. 2009. Land use and land cover change in Greater Dhaka, Bangladesh: Using remote sensing to promote sustainable urbanization. Applied Geography, 29: 390-401.

Firman, T. 2004. Major issues in Indonesia's urban land development. Land Use Policy, 21: 347-355.

Hadi, S. 2012. Model spasial penggunaan lahan dan arahan rencana penggunaan lahan di Kabupaten Bogor [Tesis]. IPB. Bogor.

Ilham, N.Y., Syaukat, dan S. Friyanto. 2005. Perkembangan dan faktor-faktor yang mempengaruhi konversi lahan sawah serta dampak ekonominya. SOCA, 5: 203-212.

Irawan, B. dan S. Friyatno. 2002. Dampak konversi lahan sawah di Jawa terhadap produksi beras dan kebijakan pengendaliannya. Jurnal SosialEkonomi Pertanian dan Agribisnis SOCA, 2: 79-95.

Pribadi, D.O., D. Shiddiq, dan M. Ermyanyla. 2006. Model perubahan tutupan lahan dan faktor-faktor yang mempengaruhinya. Jurnal Teknologi Lingkungan, 7:35-51.

Rustiadi, E., D.R. Panuju, dan B.H. Trisasongko. 2008. Environmental impacts of urbanization in Jabodetabek Area. Joint JIRCAS-ICALRD Symposium, Bogor.

Trisasongko, B.H., D.R. Panuju, L.S. Iman, Harimurti, A.F Ramly, V. Anjani, dan H. Subroto. 2009. Analisis dinamika konversi lahan di sekitar jalur tol cikampek. Publikasi Teknis DATIN. Kementerian Negara Lingkungan Hidup. Jakarta. 